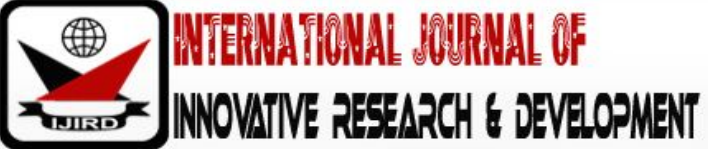

ISSN 2278 - 0211 (Online)

\section{Job Security and Employees Performance in Nigeria Private Sector}

Udeobasi Obianuju Chinyelu

Lecturer, Department of Sociology/ Anthropology, Nnamdi Azikiwe University, Awka, Nigeria

\begin{abstract}
:
This study set out to examine the effect of job security on employee performance in the private sector taking cognizance that employee performance play important role for organizational performance. It was anchored on victor vrooms expectancy theory which argues that humans are capable of making choices and are able to think rationally. Consequently, they strive to attain rewards that they value which in turn affects performance. The research design adopted for this study was the cross sectional survey. A sample size of 500 respondents was used for this study. Findings from the study show that job security virtually do not exist in Nigeria private sector however if employees are assured of their jobs their loyalty to the organization will positively improve their performance. The study recommends that Management should assure employees of job security, a condition precedent to employees' loyalty and commitment to the organization. Job security is necessary if private sector employees are to perform maximally.
\end{abstract}

Keywords: Job security, employee performance, private sector

\section{Introduction}

Organizations today are very concerned about the performance of their employees. This is because the performance of the employees will directly affect the performance of the organizations. Rewards are among the important elements that motivate employees to contribute their best effort to generate innovative ideas that lead to improved business and service delivery. An effective reward system can stimulate employees to work harder thus increasing productivity and enhancing job performance (Lin, 2007). At work, motivation is a combination of all factors in our working environment that lead to positive or negative efforts. If we understand what motivates us, we are more likely to achieve our personal and professional goals. Likewise, if organizations know how to motivate employees, they can increase productivity. This ability to boost production is increasingly important as organizations compete in the global market. The strongest motivator, according to Wiley (1997) is something that people value but lack. This lack translates to job security in the Nigeria private sector.

With embargo placed on government employment in Nigeria and with the neo liberal policies of government, the private sector in Nigeria is increasingly becoming the engine of growth and a source of employment. According to IDS Pay Report (2011) the private sector contains a wide variety of employees, with a high ratio of unskilled workers with few qualifications and employees at the top of their professions. It has the largest number of the highest-paid employees (in finance and business services) and the largest number of the lowest-paid (in retailing, hotels and restaurants and cleaning), as well as all those in between. These structural differences produce predictably different income distributions and influence the importance of different types of reward to each employee. However the restructuring and downsizing private organizations have embarked on to reduce labor cost and improve profitability has cast a shadow of uneasiness and tension among workers as no one is sure who will be next. An employee expectation is to be treated fair. However with the tension in the workplace, employees will not go the extra mile nor bring in their ingenuity when they don't know what their status is because there are no set standards as to who stays in the organization could be measured and this in turn affects their performance. Therefore this paper examines the effect of job security on employee performance in the private sector.

\section{Literature Review}

According to Hodson\& Sullivan, (2002) job security is an expectation that employees can keep their jobs over a period of time. It means that an employee cannot be dismissed from the job arbitrarily. An employee would be more committed to his/ her job and the organization, if he or she feels secure. According to Lambert (1991) it is an extrinsic reward that has a positive relation with workers' commitment and performance. Hence job security is an important factor to employee performance. Job security is one of the most influential means of motivating employees particularly in times of economic downturn. Employee's belief that they will not lose their job or they will be employed in the same organization as long as they want is a significant reason for performance. According to Arabi (2000), job security is the 
feeling of having a proper job and the assurance of its continuance in future as well as the absence of threatening factors. It plays an important role in both social and working life because it helps employees not to worry about their future, contribute to maintain labor peace, increase organizations productivity, personal advancement, protecting social balance and values (Guzel 2001). Robbins, (1998), posits that job security is one of the creators of job satisfaction and commitment to the company which may result in the worker investing more time and effort into their companies. Therefore job security is one of the most significant variables of employee satisfaction which expresses the general attitude of the employee to his or her job (Bakan and buyukbese 2004: 35). On the other hand, when job security is perceived negatively, employees cannot be expected to transfer their knowledge and experience into their work. For this reason, organizations should provide lifelong job security to their employees and adopt management policies which offer assurance in order to motivate them (Brisling, Kabigting, Macnab, Zukis and Worthley 2005).It is documented that people who feel secure in their work are more productive than people who do not (Castilla, 2005). The trust level has a significant effect on the work behaviors of employees (Dar, 2010). As a consequence of these feelings of being valued and experiencing less stress, employees feel more satisfied with their job and are less inclined to have intentions to quit the organization (Levy, 2006). With the current state of the economy, Workers will show you loyalty when they feel valued, sure of their tenure and are recognized for the contributions they make. This plays an essential part in enhancing employee performance towards organizational tasks.In a related study, Kulkarni (1983) compared the relative importance of extrinsic factors.The result revealed job security as the most important. Job security was also seen as one of the motivational factors by $75 \%$ of the respondents. Aktar, Sachu and Ali (2012) on the impact of rewards on employee performance on 180 bank employees still show that job security is a highly significant factor which affects employee performance. This is in line with the findings of Qayyum and Sukirno (2012) on employee motivation and the role of demographics on 200 (82.5\%) bank employees high salary, job security was ranked among the most important motivational factor confirming that it has become a critical factor in a society where people strive to achieve and maintain high social status.

Finally, private organizations have been downsizing, restructuring and merging with increasing frequency over the past years. For employees, these major changes have caused feelings of anxiety, stress and insecurity concerning the nature and continued existence of their jobs. According to Romzek (1985), perceived insecurity can have a direct impact on all these behaviors. For example, an employee who thinks their job is at risk may be more likely to be looking for work elsewhere, tell others negative things about the organization, and exert less effort in their work if they think they do not have a future there. James (2012), argue that job security has a significant effect on the overall performance of the employees as well as on the organization's performance. He noted that organization with workers with low job security causes people to lose faith in their future which consequently affect performance. He affirms that the more an employee enjoys high security the more likely to effectively perform his task which is reflected in the overall performance of the organization.

\subsection{Theoretical Context of Job Security and Employee Performance}

This study builds its theoretical foundation on Victor Vroom's expectancy theory (1964). This is one of the most well-known key process theories and is the most common theory that private sector organizations attempt to implement (Ambrose and Kulik, 1999). According to expectancy theory, employees will exert effort to achieve organizational goals if they are offered rewards that are valuable to them. This theory links hard work and high performance with desired rewards. This is in line with the notion of hedonism and the wish for enjoyment, which in this case is rooted in valued rewards. Expectancy theory argues that humans are capable of making choices and are able to think rationally. Consequently, they strive to attain rewards that they value (Mitchell, 1973). People are ready to own organizational goals if the achievement of those goals contributes, directly or indirectly, to their personal objectives (Simon, 1970).

Jurkiewicz Massey and Brown(1998) describe expectancy theory in even simpler words. According to them, people join organizations with certain values and expectations. If their values and expectations are met, they put forth high levels of effort to achieve organizational goals, and are expected to remain with the organization for long periods of time. On the other hand, if there is a substantial gap between what employees wants from their jobs and what they get, they are not motivated, resulting in high levels of staff turnover or attempts by staff to find other ways to fulfill their expectations.

\subsection{Methods}

The research design adopted for this study was the cross sectional survey. It used both quantitative and qualitative methods. The sample size was determined using multi- stage sampling technique, purposive sampling, stratified sampling and simple random sampling technique. Data was collected using the questionnaire schedule, Key informant interview (KII) guide and in depth interview (IDI) guide. The quantitative data were analyzed with descriptive statistics, while the qualitative data was analyzed using thematic content analysis. 


\section{Data Analysis}

\begin{tabular}{|c|c|c|c|}
\hline \multirow{2}{*}{ Responses } & \multicolumn{3}{|c|}{ Organization } \\
\cline { 2 - 4 } & Bank & Pharmaceutical & TOTAL \\
\hline Yes & $215(87.8 \%)$ & $231(96.2 \%)$ & $446(92.0 \%)$ \\
\hline No & $18(7.3 \%)$ & $6(2.5 \%)$ & $24(4.9 \%)$ \\
\hline Not Sure & $12(4.9 \%)$ & $3(1.2 \%)$ & $15(3.1 \%)$ \\
\hline Total & $245(100 \%)$ & $240(100 \%)$ & $485(100.0 \%)$ \\
\hline
\end{tabular}

Table 1 Distribution of Respondents by Their Views on the Effect of Job Security on Employee Performance Source: Field Survey, 2014

Table 1 shows that $87.8 \%$ from Bank and 96.2\% from Pharmaceutical will be motivated to perform better if they are guaranteed of their jobs.

A KII participant from Bank affirmed that the more an employee enjoys high job security, the more he is likely to perform highly. The respondent indicated as follows:

Despite economic pressures on the company, job security depends on whether the individual is employable or not and if business has a need for their skills or not. In other words, individuals need to have the right skill set to have good job security. If not, frustration 'go pursue you kiakia' because there won't be any kind of promotion for you. (Male, 42 years)

Another participant from the same organization said

Here there is no job security; in fact we have already been paid our gratuity so the bank does not owe us anything except our monthly salary. So if your score card is less than $75 \%$ over time, just start looking for another job. (Female, 33 years)

In Pharmaceutical a KII participant remarked as follows:

In the private sector, job security is zero. "Onyealuroofumaachuoya". This coupled with those who peddle gossip to "Oga" on the things happening inside here. So we mind our own business before they report you and you go. (Male, 33 years)

In another analysis respondents indicated job security as a factor hindering employee performance.

\section{Major problems associated with Reward Systems and Employee Performance}
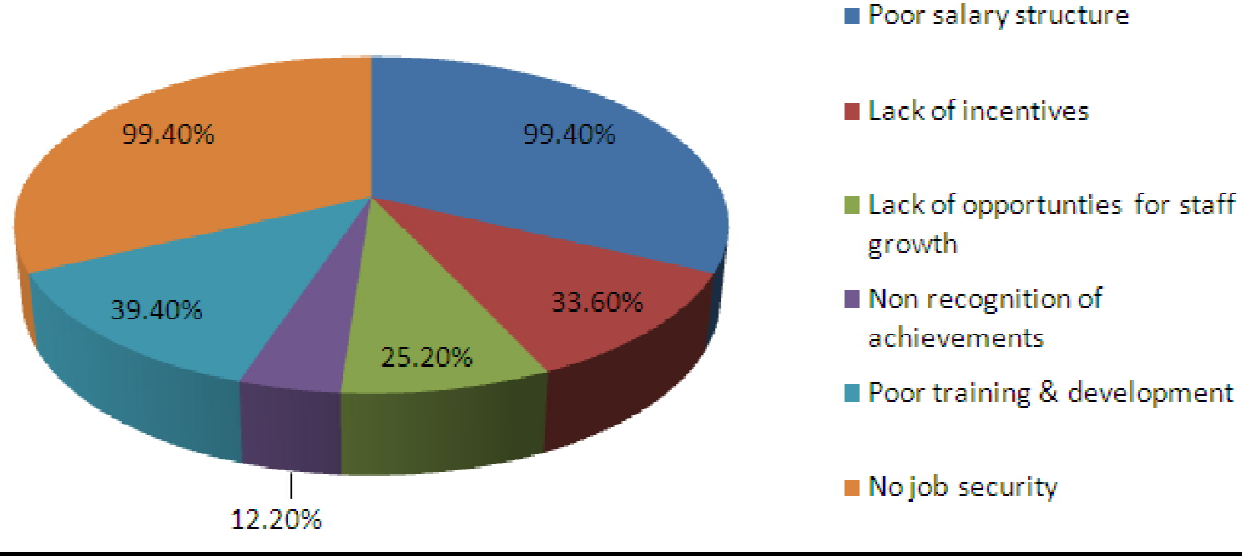

Figure 1: Major Problems Associated with Reward System and Employee Performance

\section{Discussion of Findings}

Clearly the result shows that job security got the highest rating by most as a factor hindering employee performance. This means that employees are willingly to work so far there is assurance of their stay in the organization. Furthermore the result of the study shows that job security is another important factor that motivates employee performance. Robbins (1998) listed job security as one of the creators of job satisfaction and commitment to the company which may result in the worker investing more time and effort into their companies. Baah and Amoako (2011) affirmed that job security means survival for African employees. Brisling et al (2005) reveal that when job security is perceived negatively there would be the tendency for employees not to transfer their knowledge and experience into their work. The KII participants from the organizations of study affirmed that job security motivates, however it is not common in the private sector. 


\section{Conclusions}

The study found that improving job security, will lead to employee performance. In view of the findings of this study, it can be inferred that workers place great value on job security from their employers. Hence when this is not given workers tend to express their displeasure through poor performance and non-commitment to their job. It is therefore crucial for organization to consider the feelings of its work force and not to overlook them in order to safeguard industrial harmony, because "a happy worker they say is a productive worker". It is however worth emphasizing that in as much as it appears that employees is more concerned with job security and hence extrinsic rewards, the intrinsic rewards also play a role in employee motivation although they may not be the dominant motivation in the Nigerian situation. The study can therefore be seen as a call for employers' good judgment to be ingenious in situating proper motivation plan that will persuade workers to be more purposeful and improve their performance. Therefore the study recommends thatManagement should assure employees of job security, a condition precedent to employees' loyalty and commitment to the organization. Job security is necessary if private sector employees are to perform maximally.

\section{References}

i. Aktar, S., Sachu, M.M \& Ali, M.E. (2012).The Impact of Reward on Employee Performance in Commercial Banks in Bangladesh: An Empirical Study. IOSR Journal of Business and Management 6(2) 9-12.

ii. Ambrose, M.L. and Kulik, C.T. (1999), "Old friends, new faces: motivation research inthe1990s. Journal of Management, Vol. 25, No. 3, pp. 231-92.

iii. Arabi, S.M. (2000). Strategies, Plans and Guidelines to Achieve Job Security. Management Studies Quarterly, 37

iv. Baah, K.D. \&Amoaka, A.K. (2011). Application of Herzbergs two factor theory in assessing and understanding employee motivation at work. European Journal of Business \&Management Vol. 3 No 9 (22-29)

v. Bakan\&Buyukbese, T. (2004). The relationship between organizational communication and aspects of job satisfaction. Akdenizuniversity: Journal of Economics \& Administrative Science 17(1-30).

vi. Brisling, R.W., Kabigting, F., Macnab, B. Zukis, B. Worthley, R., (2005). Evolving perceptions of Japanese work place Motivation. International Journal of Cross Cultural Management 5 (1)87- 103.

vii. Castilla, E.J. (2005). Social Networks and Employee Performance in a Call Center.Annual Journal of Sociology. 110(5): 1243-1283.

viii. Dar, O.L. (2010). Trust in Co-workers and Employee Behaviors at Work. International. Review of Business. Research Papers, 6(1): 194-204.

ix. Huddleston, P., Good, L. \& Frazier, B. (2002). The Influence of Firm characteristics and Demographic Variables on Russian workers work motivation and job attitudes International Review of Retail, Distribution and Consumer Research 12(4), 395- 421.

x. James 2012. How to achieve true job security.http://www.inc.com/geofrey-james/ how-to-achieve-true-jobsecurity.hmtl

xi. Kulkarni, P. (1983). Organizational Behavior and Human Decision Processes. New Delhi:McCoy Hill.

xii. Levy, P. E. (2006).Industrial and Organisational Psychology: Understanding the Workplace (2nd ed.)Boston; Houghton Mifflin Company.

xiii. Lin, HF. (2007). Effects of extrinsic and intrinsic motivation on employee knowledge sharing intention. Journal of Information Science, 33(2):135-158.

xiv. Mitchell, T.R (1982). Motivation: New directions for Theory, research and practice. The Academy of management review (7)1:80-88e

xv. Qayyum, A. and Sukirno (2012). An empirical analysis of employee motivation and the role of demographics: The banking industry of Pakistan. International journal of global business and management research 4(1).

xvi. $\quad$ Robbins, S. P. (1998). Organizational Behavior. (8th edition).New Jersey: Prentice Hall.

xvii. Romzek, B.S (1985) the effect of public service recognition, job security and staff reductions on organizational involvement. Public Administration Review (45) 282-292.

xviii. Vroom, V. H. (1964). Work Motivation. New York: John Wiley and Sons.

xix. Wiley, C (1997). What motivates employees according to over 40 years of motivation survey? International journal of man power 3(4), 221-232. 